\title{
PENGEMBANGAN MATERI AJAR BAHASA MAKASSAR BERBASIS NILAI-NILAI KARAKTER DAN KEARIFAN LOKAL DI SEKOLAH DASAR KOTA MAKASSAR ${ }^{1}$
}

\author{
Sitti Rabiah ${ }^{2}$ \\ Fakultas Sastra \\ Universitas Muslim Indonesia
}

\begin{abstract}
Abstrak
Globalisasi dan kemajuan teknologi seringkali dituding sebagai ancaman atas hilangnya nilai-nilai karakter dalam diri seseorang dikarenakan dampak negatif yang ditimbulkan dapat menyerang siapapun, termasuk didalamnya siswa sekolah dasar. Padahal kedua hal ini tidak dapat dibendung lagi, hal yang dapat dilakukan yakni melakukan tindakan-tindakan preventif, salah satunya di lingkungan sekolah yang mengajarkan pendidikan karakter yang terintegrasi dengan mata pelajaran. Makalah ini membahas langkah-langkah dalam mengembangkan materi ajar bahasa Makassar berbasis nilai-nilai karakter dan kearifan lokal di sekolah dasar. Pembahasan ditinjau dari sisi teoretis, dan aplikatif sehingga memudahkan peneliti selanjutnya untuk melakukan penelitian serupa dengan objek yang berbeda. Penelitian dilakukan dengan metode penelitian dan pengembangan oleh Borg dan Gall dilengkapi dengan konsep lainnya. Temuan dari penelitian ini yakni model materi ajar bahasa Makassar yang telah dikembangkan dan dinamakan "Pappilajarang Basa Mangkasarak" untuk kelas IV SD. Di setiap materinya telah terpadu nilainilai karakter serta kearifan lokal yang dapat meningkatkan semangat belajar siswa dan menghilangkan kesan ketinggalan zaman yang seringkali disematkan pada bahasa Daerah. Rekomendasi dari makalah ini yakni mendorong Dinas Pendidikan setempat untuk mengembangkan materi ajar berbasis nilai-nilai karakter dan mengangkat kearifan lokal setempat.
\end{abstract}

Kata Kunci: Materi Ajar, Bahasa Makassar, Karakter, Kearifan Lokal

\begin{abstract}
Globalization and technological advances are often accused of being threats to the loss of character values in a person due to the negative impacts can strike anyone, including elementary school students. Though both of these things can not be stopped, things to do that do preventive measures, one of them in a school environment that teaches character education integrated with subjects. This paper discusses the steps in developing teaching materials Makassarese language based on character values and local wisdom in elementary school. Discussion in terms of the theoretical and applicative makes it easier for the next researcher to conduct similar studies with different objects. Research carried out by the method of research and development by Borg and Gall equipped with other concepts. The findings of this study that models the Makassarese language teaching materials have been developed and named "Pappilajarang Basa Mangkasarak" for fourth grade elementary school. Inside the material has been integrated character values and local wisdom that can improve students' learning spirit and eliminate outdated impression is often pinned on regional language. Recommendation of this paper that is pushing the Education Department to develop teaching materials based on the values and character of the local indigenous lifted.
\end{abstract}

Keywords: Learning Material, Makassarese Language, Character Building, Local Wisdom

\footnotetext{
${ }^{1}$ Makalah telah dipresentasikan dalam Konferensi Internasional Budaya Daerah (KIBD) III yang diselenggarakan oleh Ikatan Dosen Budaya Daerah Indonesia (Ikadbudi) pada 7-8 Desember 2013 di Sukoharjo, Indonesia.

2 (D) https:// orcid.org/ 0000-0002-1690-0025. Kontak penulis: sitti.rabiah@umi.ac.id / sittirabiah25@gmail.com
} 


\section{A. PENDAHULUAN}

Memasuki era globalisasi ancaman hilangnya karakter semakin nyata. Nilainilai karakter yang luhur tergerus oleh arus globalisasi, utamanya kesalahan dalam memahami makna kebebasan dalam kerangka demokrasi serta rendahnya pemahaman masyarakat terhadap esensi kemajuan teknologi. Pada dasarnya kemajuan teknologi merupakan pisau bermata dua, disatu sisi memberi kemudahan bagi manusia, namun disisi lain juga memberi dampak negatif jika disalahgunakan.

Di samping itu, teknologi juga dapat menjadi media penghancur umat manusia setidaknya karena tiga hal. Pertama, teknologi cenderung memudahkan, bisa menjebak seseorang menjadi sosok serba instan atau manja dan tidak menghargai proses; Kedua, teknologi memang bisa mendekatkan yang jauh, tetapi bisa juga menjauhkan yang dekat. Seseorang bisa menjadi asing di lingkungan sekitarnya dan bisa saja tak peduli dengan sekelilingnya jika terlalu intens dalam penggunaan teknologi; ketiga, teknologi bisa memicu perilaku konsumtif, orang jadi selalu mengejar produk terbaru atau membeli promo-promo yang ditawarkan di dunia maya. (Setiawan Dani dalam Barnawi dan M. Arifin, 2012:14)

Kebebasan sebagai anak kandung demokrasi seringkali diterjemahkan sebagai kebebasan berkehendak tanpa aturan yang baku. Hal ini mengindikasikan bahwa konsep nilai menjadi sesuatu yang relatif. Ada pola tertentu (particular pattern) yang justru mengesampingkan pola umum (universal pattern). Maka, menjadi tidak mengherankan ketika foto-foto dan pose-pose bugil dan sesuatu yang mestinya menjadi ranah privat, masuk ke dalam ruang publik. Dampak jelas, banyak orang yang terkena imbasnya, merasah risih, terganggu, bahkan tidak sedikit yang terintimidasi seperti para siswa yang sering di razia karena dicurigai mengoleksi adegan porno mirip artis terkenal.

Fenomena rusaknya karakter akan semakin cepat ketika pengguna teknologi tidak memahami esensi kemajuan teknologi, akibatnya pengguna ini seringkali salah dalam memanfaatkan dan memandang nilai fungsi teknologi. Sebagai contoh, fungsi telepon seluler yang semestinya untuk komunikasi dan menyimpan data penting banyak oleh penggunanya disalahgunakan. Penyalahgunaan ini disebabkan karena mereka tidak memiliki pengetahuan teknologi yang cukup. Maka, apabila telepon seluler tersebut berpindahtangan, maka data yang bersifat privat dapat dengan mudah disebarkan oleh pihak-pihak yang tidak bertanggungjawab, termasuk didalamnya hal-hal yang privat dan tidak sengaja terdokumentasi dalam telepon seluler tersebut.

Potret di atas cukup menjelaskan pada kita bahwa saat ini nilai-nilai karakter mengalami ancaman dari globalisasi dan kemajuan teknologi. Namun demikian, kita tentunya tidak dapat menahan masuknya dua hal tersebut. Hal yang dapat kita lakukan yakni melakukan tindakan-tindakan preventif agar dampak negatif dari kedua hal tersebut dapat diminimalkan. Pihak yang paling besar kemungkinannnya menerima dampak negatif yang cukup signifikan dari kedua hal tersebut adalah generasi muda, khususnya siswa yang berada pada jenjang Sekolah Dasar. 
Kondisi mental dan psikologis siswa sekolah dasar yang belum dapat menyaring informasi menjadi hal yang paling dikhawatirkan menjadi pintu masuk dari dampak negatif yang ditimbulkan. Apabila dampak negatif tersebut terus menerus diterima, maka besar kemungkinan akan berakibat pada karakter yang dimiliki. Kecenderungan siswa akan mengikuti anjuran-anjuran yang disampaikan dalam media yang diikutinya, sekalipun itu negatif dan merusak diri sendiri.

Maka dari itu, intensifikasi nilai-nilai karakter seyogyanya harus dilakukan setiap waktu, baik di lingkungan keluarga melalui teguran atas perilaku siswa yang dianggap tidak sesuai norma, maupun lingkungan pendidikan formal yakni sekolah dengan cara meningkatkan usaha-usaha dalam rangka menanamkan nilai-nilai karakter pada peserta didik/siswa.

Selanjutnya makalah ini akan membahas lebih lanjut upaya penanaman karakter melalui institusi pendidikan formal yakni sekolah. Khususnya dalam hal pengembangan materi ajar bahasa Makassar yang berbasis pada nilai-nilai karakter dan kearifan lokal. Harapannya melalui pembahasan di makalah ini dapat menyumbangkan pemikiran dan gagasan untuk menindaklanjuti upaya reaktualisasi pembelajaran bahasa dan sastra daerah dalam kerangka pembentukan karakter generasi penerus bangsa.

\section{B. INTERNALISASI NILAI-NILAI KARAKTER DALAM PENGEMBANGAN MATERI AJAR BAHASA MAKASSAR}

Bagian ini akan membahas lebih lanjut mengenai materi ajar bahasa Makassar serta pengembangannya dalam model pembelajaran serta langkah-langkah menginternalisasikan nilai-nilai karakter didalamnya.

\section{Definisi Model Pembelajaran}

Menurut Pribadi, model pembelajaran pada dasarnya merupakan bentuk pembelajaran yang tergambar dari awal sampai akhir yang disajikan secara khas oleh dosen atau pengajar. Bentuk pembelajaran dimaksud merupakan suatu proses yang menggambarkan adanya pola berpikir, sekaligus sebagai keseluruhan konsep yang saling berkaitan. Dikatakan sebagai pola berpikir, karena model ini dapat diartikan sebagai suatu rangkaian pendekatan, strategi, metode, teknik dan bahkan taktik pembelajaran yang menjadi satu dan utuh. (Pribadi, 2010:86)

Dari pendapat yang dikemukakan Pribadi dapat diartikan bahwa model pembelajaran mempunyai ciri khas dari dosen atau pengajar dalam menyusunnya, sedangkan bentuknya terdiri dari penggambaran dari awal hingga akhir dalam satu kesatuan yang terpadu.

Soekamto dkk. dalam Trianto menyatakan bahwa model pembelajaran adalah kerangka konseptual yang melukiskan prosedur sistematis dalam mengorganisasi pengalaman belajar untuk mencapai tujuan belajar tertentu, dan berfungsi sebagai pedoman bagi perancang pembelajaran dan pengajar dalam merencanakan aktivitas belajar mengajar. (Trianto, 2011:22) 
Pendapat Soekamto dkk. dalam Trianto dapat diartikan bahwa model pembelajaran merupakan acuan dalam proses belajar mengajar bagi perancangan pembelajaran maupun pengajar, namun demikian model tersebut harus tersusun secara sistematis dari dan terorganisir.

Istilah model juga dapat diartikan sebagai suatu bentuk atau pola hasil pengembangan untuk menemukan sesuatu yang baru menurut kaidah dan metode tertentu sehingga melahirkan formulasi baru yang dikehendaki. Hasil dari pengembangan model pembelajaran adalah seperangkat kegiatan yang terdiri dari perencanaan, pengembangan, dan evaluasi sistem pembelajaran untuk memperoleh serangkaian proses atau kegiatan yang menghasilkan suatu perangkat pembelajaran berdasarkan teori pengembangan yang telah ada.

Selanjutnya Joyce dkk. (2009:7), menyatakan bahwa model-model pengajaran sebenarnya juga bisa dianggap sebagai model-model pembelajaran. Lebih lanjut dikatakan bahwa saat ini tugas pendidik adalah membantu peserta didik memperoleh gagasan, informasi, skill, nilai, cara berpikir, dan tujuan mengekspresikan diri mereka sendiri. Jadi tugas guru sebenarnya hanya mengajari mereka untuk belajar. Dalam hal ini, model pembelajaran memiliki tujuan untuk membantu peserta didik dalam belajar melalui pengaturan lingkungan belajar sehingga proses belajar pada diri mereka dapat terjadi. Lingkungan belajar dalam pengertian ini, mencakup: (a) situasi pembelajaran, (b) aktivitas belajar, (c) materi pembelajaran, (d) media lainnya yang berpengaruh langsung terhadap kemungkinan terjadinya proses belajar pada diri mahasiswa.

Berdasarkan pendapat di atas, model pembelajaran dapat diartikan sebagai cara membuat pola atau merancang suatu proses pembelajaran yang akan diterapkan pada lingkungan belajar yang sesuai atau tepat dengan tujuan belajar. Untuk menerapkan model pembelajaran, guru diharapkan dapat memperhatikan masalah-masalah dalam pembelajaran dengan kondisi tertentu yang dialami oleh siswa. Apabila guru mengetahui dan memahami permasalahan/kondisi tertentu yang dialami siswa, maka langkah selanjutnya adalah mencari, menelaah, menerapkan strategi yang tepat dalam memfasilitasi belajar mahasiswa agar tujuan belajar dapat tercapai.

Dengan demikian, suatu model pada dasarnya adalah suatu proses yang bersifat linear yang diawali dengan penentuan kebutuhan, selanjutnya mengembangkan rancangan untuk merespon kebutuhan tersebut, kemudian rancangan tersebut diujicobakan dan akhirnya dilakukan proses evaluasi untuk menentukan hasil tentang efektifitas rancangan (desain) yang telah disusun.

Dari paparan di atas dapat disimpulkan bahwa model merupakan suatu kerangka konseptual yang melukiskan prosedur sistematis dalam mengorganisasi pengalaman belajar untuk mencapai tujuan belajar tertentu berupa rangkaian pendekatan, strategi, metode, dan teknik pembelajaran. Dengan kata lain, model pembelajaran merupakan bungkus atau bingkai dari penerapan suatu pendekatan, metode, dan teknik pembelajaran. Apabila pendekatan, strategi, metode, teknik dan taktik pembelajaran sudah terangkai menjadi satu kesatuan yang utuh, maka terbentuklah apa yang disebut dengan model pembelajaran. 


\section{Hakekat Pengembangan Model}

Berikut ini merupakan pendapat dari beberapa ahli mengenai pengembangan model. Menurut Mulyana (2003:42-47), pengembangan model bahan ajar bahasa adalah kegiatan yang diawali dari penelitian untuk mendapatkan gambaran tentang dokumen bahan ajar bahasa dan pembelajarannya serta kebutuhan para siswa Sekolah Dasar dan dilanjutkan oleh kegiatan pengembangan bahan ajar bahasa melalui beberapa kali uji coba bahan ajar yang berterima dan objektif dengan tahap-tahap yang akan dirancang oleh peneliti sehingga mendapatkan bahan ajar bahasa yang efektif, baik dari aspek pengetahuan bahasa yang terdiri atas fonologi, morfologi, sintaksis, dan semantik serta empat keterampilan berbahasa, yaitu keterampilan mendengar, keterampilan berbicara, keterampilan membaca, dan keterampilan menulis.

Definisi yang dipaparkan Mulyana di atas menerangkan bahwa proses pengembangan model bahan ajar terdiri dari serangkaian tahap yang diawali dengan mengembangkan bahan ajar kemudian melewati serangkaian uji coba lalu diperolehlah model bahan ajar. Dari bahan ajar yang dihasilkan tersebut, peneliti harus memperhatikan terpenuhinya komponen pengetahuan bahasa, serta empat keterampilan berbahasa.

Menurut Halim (2007:64), pengembangan model bahan ajar merupakan suatu bentuk penyederhanaan dari berbagai hal yang kompleks sehingga pemecahannya menjadi mudah dan sederhana, dapat ditampilkan bagian-bagian utama yang penting dan perlu. Secara spesifik, pengembangan bahan ajar muatan lokal bahasa Makassar berarti mengembangkan bahan ajar muatan lokal yang dibuat oleh dinas terkait yang disesuaikan dengan kurikulum yang berlaku untuk mendapatkan model bahan ajar muatan lokal yang efektif dan efisien.

Hal yang dikemukakan Halim (2007:64) lebih menyederhanakan definisi dari pengembangan model. Ia lebih menekankan bahwa model merupakan sarana untuk menyederhanakan hal yang bersifat kompleks menjadi mudah dan sederhana, namun tetap memperhatikan bagian utama dan prioritas.

Dengan demikian, secara teoretis, pengembangan model bahan ajar bahasa dilakukan dengan tiga cara, yaitu secara sistemik, proses, dan objektif.Secara sistemik berarti pengembangan model bahan ajar bahasa mencakup; (a) unsur-unsur bahan ajar , isi bahan ajar, dan desain bahan ajar yang sesuai dengan kebutuhan para pembelajar atau siswa di sekolah dasar serta (b) pengembangan komponen pembelajarannya, seperti tujuan, pendekatan, metode, teknik dan evaluasi. Secara proses, pengembangan bahan ajar bahasa dilakukan secara bertahap dengan prinsip pengembangan adanya skala prioritas, pentahapan, teliti, serta adanya unsur menarik.

\section{Konsep Model yang Dikembangkan}

Pada hakikatnya, model merupakan suatu kerangka konseptual yang melukiskan prosedur sistematis dalam mengorganisasi pengalaman belajar untuk mencapai tujuan belajar tertentu berupa rangkaian pendekatan, strategi, metode, dan teknik 
pembelajaran. Dengan kata lain, model pembelajaran merupakan bungkus atau bingkai dari penerapan suatu pendekatan, metode, dan teknik pembelajaran. Apabila pendekatan, strategi, metode, teknik dan taktik pembelajaran sudah terangkai menjadi satu kesatuan yang utuh, maka terbentuklah apa yang disebut dengan model pembelajaran.

Kaitannya dengan pengembangan model bahan ajar bahasa Makassar yakni suatu konsep yang dikembangkan untuk menghasilkan produk bahan ajar berdasarkan analisis kebutuhan terhadap siswa sekolah dasar sebagai target produksi. Dalam pengembangan model pembelajaran ini, model yang dikembangkan Borg dan Gall dijadikan sebagai pedoman atau acuan dalam mengembangkan konsep/kerangka dasar model pembelajaran yang sistematis. Selain itu, penulis juga mengadopsi model yang dikembangkan oleh Brown terkait dengan fase pengembangan model bahan ajar yang diklasifikasi menjadi tiga tahap utama yakni: pengembangan, implementasi, dan evaluasi.

Untuk selanjutnya dalam penelitian ini akan digunakan dua model pengembangan oleh Borg dan Gall, serta Brown sebagai acuan dalam langkah-langkah penelitian yang akan ditempuh dalam menyusun model bahan ajar bahasa Makassar sebagai muatan lokal untuk siswa sekolah dasar di kota Makassar.

\section{Model Research and Development (Borg dan Gall)}

Research and Development (R\&D) secara sederhana dapat didefinisikan sebagai metode penelitian yang digunakan untuk menghasilkan produk tertentu, dan menguji keefektifan produk tersebut. Dari definisi ini, penelitian dan pengembangan berimplikasi pada dua titik utama yaitu, produk dan efektifitas. Penelitian dan pengembangan didefinisikan sebagai suatu proses atau langkah-langkah untuk mengembangkan suatu produk baru atau menyempurnakan produk yang telah ada, yang dapat dipertanggung jawabkan.

Dengan demikian, R\&D dapat juga diartikan sebagai suatu proses yang diupayakan melahirkan produk baik yang $100 \%$ baru maupun modifikasi dan inovasi produk yang sudah ada tetapi tetap memiliki kesahihan, validitas dan keterpercayaan melalui suatu proses dengan kriteria dan standar ilmiah yang telah ada secara berulangulang.

Berkaitan dengan kompleksitas mekanisme dan langkah-langkah penelitian dan pengembangan bidang pendidikan Borg dan Gall (2003:542-543) menyatakan ada sepuluh langkah dalam sebuah pelaksanaan penelitian dan pengembangan dalam bidang pendidikan dari yang sangat awal (preliminary) sifatnya hingga yang bersifat diseminasi hasil penelitian. Berikut ini adalah langkah-langkah sistematis metode penelitian dan pengembangan menurut Borg dan Gall.

Pertama yang dilakukan adalah analisis kebutuhan (need analysis). Need analysis dilakukan melalui pengukuran dan pengumpulan data di lapangan di mana produk itu diterapkan dan kepada siapa produk itu ditujukan. itu sendiri dengan memperhatikan analisis kebutuhan. Pada tahap ini dirancang produk awal yang 
diinginkan. Produk awalnya biasa bersifat sederhana dan belum lengkap serta masih memerlukan revisi dan penyempurnaan.

Keempat, uji coba produk (preliminary field testing). Sesudah produk awal dirancang, kemudian dilakukan uji lapangan. Umumnya preliminary field testing ini dilakukan pada kelompok kecil misalnya beberapa orang pengguna seperti mahasiswa, atau dosen, dan pengguna lainnya. Tujuan dari langkah ini adalah untuk memperoleh masukan awal yang bersifat kualitatif yang diperoleh dari hasil wawancara, angket,dan observasi.

Kelima, revisi produk (revising main product), setelah masukan dan hasil evaluasi awal diperoleh, selanjutnya produk awal direvisi. Tujuan revisi adalah menyempurnakan produk tersebut agar sesuai dengan standard dan kebutuhan yang ada.

Keenam, uji coba utama (main field testing), pada langkah ini, tujuan utamanya adalah mengetahui apakah produk yang sudah dirancang memenuhi atau menjawab tujuan kinerja yang sudah ditentukan. Dalam tahapan ini, biasanya produk penelitian yang diujicobakan di lapangan sudah menggunakan desain.

Ketujuh, revisi produk operasional (operational product revision), jika main field testing masih belum memenuhi atau menjawab masalah dalam penelitian, revisi produk sangat perlu dilakukan. Siklus uji coba dan revisi ini akan berlangsung terus hingga produk yang dihasilkan memenuhi standar kinerja atau tujuan kinerja penelitian tercapai.

Kedelapan, uji coba operasional atau pengujian produk akhir (operational field testing), tujuan utama dari langkah ini adalah apakah produk yang dikembangkan benarbenar layak, valid dan terpercaya dan siap digunakan tanpa kehadiran peneliti. Dengan kata lain, langkah ini mempersiapkan produk yang siap pakai bagi pendidikan.

Kesembilan, revisi produk akhir (final product revision), langkah selanjutnya adalah revisi akhir dari produk yang dikembangkan. Revisi akhir meliputi penulisan akhir produk dengan memperhatikan penulisan secara linguistik, artistik, dan desain akhir produk yang siap untuk dicetak dan dipublikasikan, baik untuk kepentingan sendiri maupun komersial.

Kesepuluh, diseminasi dan penerapan (dissemination and implementation). Langkah terakhir dari prosedur penelitian dan pengembangan adalah diseminasi dan implementasi (penerapan). Diseminasi dan implementasi institusional meliputi misalnya seminar dan workshop dengan pihak lain, memuat dalam jurnal ilmiah, atau bekerja sama dengan penerbit yang mungkin dapat mempublikasikan dan mendistribusikan produk secara komersial.

Sepuluh langkah yang dijelaskan oleh Borg dan Gall merupakan langkah sistematis yang berfungsi sebagai pengarah bagi peneliti untuk melakukan pengembangan model bahan ajar dalam penelitian dan pengembangan berbasis pendidikan. Langkah-langkah tersebut setidaknya dijalankan secara bertahap agar mendapatkan hasil yang maksimal dan berkualitas. 


\section{Model Brown}

Brown (1995:139-140) menyatakan pengembangan model bahan ajar merupakan suatu proses yang melibatkan tiga fase utama yaitu a) mengembangkan bahan ajar, b) pembelajaran di kelas (field testing), dan c) evaluasi bahan ajar tersebut. Dalam setiap fase memiliki aktivitas masing-masing yang berbeda, secara rinci digambarkan melalui bagan dan penjelasan berikut.

Fase pertama yakni fase pengembangan terdiri dari kegiatan (a) analisis kebutuhan, (b) mendefinisikan goal dan objective, (c) melakukan tes kemampuan awal dan karakteristik siswa, dan (d) menyusun bahan ajar sebagai suatu produk. Selanjutnya, fase kedua merupakan fase implementasi pembelajaran meliputi (a) pengajaran dan pembelajaran di kelas, (b) diskusi antara pengajar dan penulis bahan ajar, serta (c) revisi untuk perbaikan akhir, kemudian fase ketiga yaitu evaluasi, dalam fase ini mencakup lima hal yakni: (a) mengevaluasi bahan ajar, (b) revisi bahan ajar, (c) menghasilkan dan mendesain akhir bahan ajar, (d) distribusi dan publikasi (internal atau eksternal dalam skala kecil atau luas), dan (e) perlu dicatat bahan ajar tidak pernah berakhir pada titik tertentu dia selalu berkembang sesuai dengan tren kebutuhan yang sangat tergantung kepada kebutuhan pembelajar pada masa tertentu.

\section{Kedudukan Bahasa Makassar}

Bahasa Makassar berkedudukan sebagai bahasa daerah. Kedudukan ini berdasarkan kenyataan bahwa bahasa Makassar menjadi bahasa pengantar dan penghubung antar penutur bahasa Makassar dan sekaligus sebagai pendukung kebudayaan masyarakat Sulawesi Selatan umumnya dan masyarakat kota Makassar khususnya. (Rabiah, 2012c) Hal ini terlihat pada penggambaran mengenai masyarakat Makassar, yang dalam tradisi sikap, serta bahasa merupakan hal yang membedakannya dengan kesatuan masyarakat lainnya. Walaupun dalam banyak tulisan, kelompok masyarakat Makassar ini disebut suku Makassar. Meskipun demikian, secara luas di masyarakat, kedua suku besar yang bermukim di Sulawesi Selatan, suku Bugis dan suku Makassar, lebih lazim disatukan menjadi suku Bugis-Makassar. Dalam kenyataannya, memang tidak banyak perbedaan, yang menonjol hanyalah pada bahasa yang digunakannya. Oleh karena itu, sebutan tentang masyarakat Makassar lebih sering dikaitkan dengan penutur bahasa Makassar. (Wahid, 2007:27-28)

Menurut Alwi dan Sugono (2003:40), kedudukan bahasa daerah harus dilihat dua sudut pandang: (1) bahasa daerah sebagai sarana komunikasi bagi para penutur yang berasal dari kelompok etnik yang sama, dan (2) bahasa daerah dalam kaitannya dengan bahasa Indonesia.

Dilihat dari kedudukan yang disebutkan pertama, bahasa daerah berfungsi sebagai (1) lambang kebanggaan daerah, (2) lambang identitas daerah, (3) alat penghubung di dalam keluarga dan masyarakat daerah, (4) sarana pendukung budaya daerah dan bahasa Indonesia, dan (5) pendukung sastra daerah dan sastra Indonesia. 
Akan tetapi, dari kelima fungsi ini tampak bahwa empat fungsi belum berjalan sebagaimana yang diharapkan.

\section{Internalisasi Nilai-Nilai Karakter melalui Pembelajaran}

Mengacu pada Kaidah Pembinaan Pendidikan Karakter oleh Kementerian Pendidikan dan Kebudayaan, pada dasarnya pendidikan karakter dalam pembelajaran diliputi prinsip-prinsip sebagai berikut: (1) mempromosikan nilai-nilai dasar etika sebagai basis karakter, (2) mengidentifikasi karakter secara komprehensif supaya mencakup pemikiran, perasaan, dan perilaku, (3) menggunakan pendekatan yang tajam, proaktif, dan efektif untuk membangun karakter, (4) memberi kesempatan kepada peserta didik untuk menunjukkan perilaku yang baik, (5) memiliki cakupan terhadap kurikulum yang bermakna dan menantang yang menghargai semua peserta didik, membangun karakter mereka, dan membantu mereka untuk sukses, dan (6) mengusahakan tumbuhnya motivasi diri pada peserta didik. (Asmani, 2011:56-60)

Desain sistem pembelajaran terdiri atas empat komponen yang memiliki hubungan fungsional dan saling terkait satu sama lain antara materi pembelajaran, kompetensi pembelajaran, strategi pembelajaran, dan evaluasi pembelajaran. Strategi pembelajaran yang merupakan mata rantai ketiga yang menghubungkan antara materi pelajaran dan kompetensi dari suatu materi. Sehingga menjadi hal yang harus menjadi pertimbangan dalam rangka pengembangan materi ajar.

Menurut Barnawi dan M. Arifin (2012:66-68), ada empat strategi yang ditawarkan untuk mengimplementasikan pendidikan karakter di sekolah. Pertama, strategi otonomi, yaitu dengan menempatkan pendidikan karakter sebagai mata pelajaran tersendiri. Kedua, strategi integrasi dengan menyatukan nilai-nilai dan karakter-karakter yang akan dibentuk dalam setiap mata pelajaran. Ketiga, strategi ekstrakurikuler melalui sebuah kegiatan tambahan yang berorientasi pembinaan karakter siswa. Keempat, strategi kolaborasi dengan menggabungkan ketiga model tersebut dalam seluruh kegiatan sekolah.

Lebih lanjut Kemdikbud (2011:13) memberikan masukan terkait cara-cara yang dapat ditempuh dalam rangka menginternalisasikan pendidikan karakter dalam pembelajaran bahasa yang juga menuntut kemampuan pengembang materi ajar maupun guru mata pelajaran untuk menindaklanjuti masukan tersebut. Cara yang dapat ditempuh antara lain sebagai berikut: (1) mengungkapkan nilai-nilai yang ada dalam materi pembelajaran, (2) mengintegrasikan nilai-nilai karakter menjadi bagian terpadu dari materi pembelajaran, (3) menggunakan perumpamaan, dan membuat perbandingan dengan kejadian serupa dalam hidup peserta didik (mahasiswa), (4) mengubah hal-hal negatif menjadi nilai positif, (5) mengungkapkan nilai-nilai melalui diskusi dan brainstorming, (6) menggunakan cerita untuk memunculkan nilai-nilai, (7) menceritakan kisah hidup orang-orang besar, (8) mengenalkan tokoh yang ada dalam kitab suci, (9) menggunakan drama untuk melukiskan kejadian-kejadian yang berisi nilai-nilai, dan (10) menggunakan berbagai kegiatan, seperti kegiatan amal, dan bakti 
sosial, maupun (11) praktik lapangan seperti kelompok belajar tematik antarmahasiswa.

Berdasarkan dua pandangan di atas sebagaimana dikemukakan Barnawi dan M. Arifin dan masukan dari Kemdikbud. Maka penulis dalam pengembangan materi ajar bahasa Makassar menerapkan strategi integrasi dengan menyatukan nilai-nilai dan karakter-karakter yang akan dibentuk dalam setiap mata pelajaran dari Barnawi dan M. Arifin, sejalan juga dengan cara 2 yang merupakan masukan Kemdikbud yakni mengintegrasikan nilai-nilai karakter menjadi bagian terpadu dari materi pembelajaran.

Maka dapat disimpulkan bahwa pendidikan karakter yang terpadu dalam pembelajaran merupakan pengenalan nilai-nilai, diperolehnya kesadaran akan pentingnya nilai-nilai dan internalisasi nilai-nilai ke dalam tingkah laku peserta didik sehari-hari melalui proses pembelajaran, baik yang di dalam maupun di luar kelas pada semua mata pelajaran, termasuk di dalamnya Bahasa Makassar. Integrasi pendidikan karakter pada mata pelajaran mengarah pada internalisasi nilai-nilai dalam tingkah laku sehari-hari melalui proses pembelajaran dari tahapan perencanaan, pelaksanaan, dan penilaian. Hal ini sejalan dengan pola pengembangan model pembelajaran oleh Kemdikbud yang dikenal dengan akronim ICARE (Introduction, Connection, Application, Reflection, dan Extension).

\section{NILAI-NILAI KARAKTER YANG DIKEMBANGKAN DALAM PROSES PEMBELAJARAN}

\section{Lokasi dan Sasaran Pengembangan}

Sebelum melangkah lebih jauh tentang nilai-nilai karakter yang dikembangkan dalam proses pembelajaran, terlebih dahulu perlu diketahui profil lokasi pelaksanaan, serta sasaran implementasi dari materi ajar.

Pengembangan materi ajar terlebih dahulu diawali dengan penelitian yang dilakukan pada dua sekolah dasar di kota Makassar. Kedua sekolah ini ada yang menjadi kelas kontrol, dan kelas eksperimen. Kelas kontrol merupakan kelas yang tidak diberikan perlakuan khusus, sedangkan kelas eksperimen (uji coba produk) merupakan kelas yang diberikan perlakuan khusus. Di kedua sekolah ini sebagaimana langkahlangkah dalam penelitian dilakukan uji pendahuluan (pre-test) dan diakhiri uji penutup (post-test).

Selanjutnya, sasaran implementasi materi ajar ini adalah siswa kelas IV Sekolah Dasar. Usia mereka berkisar antara 10-11 tahun. Dengan menjadi sasaran implementasi, maka materi ajar yang dihasilkan akan digunakan oleh siswa pada jenjang ini. Alasan dipilihnya jenjang ini menjadi sasaran, jika diperhatikan usia, belajar bahasa pada usia ini termasuk dalam periode operasi konkret (concrete operational period). Siswa yang berada para rentang usia ini, dapat dicirikan dengan penggunaan logika. Ciri penggunaan logika ini dapat dilihat dari aksi yang dilakukan oleh anak yang dapat melakukan sesuatu yang telah dilakukan sebelumnya secara fisik. Karakteristik utama dari rentang umur ini adalah membalik (reversibility). Kemampuan membalik ini 
dicirikan dengan kemampuan anak membalik arahan yang telah diberikan kepadanya. Ciri lainnya adalah anak dapat mengikuti rute dari sekolah dan kembali lagi ke rumah, maupun mengingat letak mainan yang ditinggalkan di suatu tempat, tanpa harus mencari ke seisi rumah.

Dalam rentang usia ini juga, anak dapat mengklasifikasikan objek berdasarkan suatu karakteristik, seperti warna, bentuk, maupun ukuran. Selanjutnya, anak diketahui dapat mendeskripsikan konservasi (conservation) sebagai kemampuan untuk melihat suatu objek atau kuantitas akan sama walaupun tampilan fisiknya berubah. (Singer dan Revenson, 1996: 22-25). Pengenalan ciri siswa sekolah dasar ini sangat penting karena mempengaruhi komponen-komponen yang dilakukan dalam rangka penelitian, maupun proses pengembangan materi ajar, seperti analisis kebutuhan, jenis tes yang diberikan, maupun pemilihan konten dan topik pada materi ajar yang dikembangkan.

\section{Nilai-Nilai Karakter}

Sebagaimana telah dipaparkan sebelumnya bahwa pada dasarnya pendidikan karakter dapat diinternalisasikan melalui proses pembelajaran secara terpadu. Berikut paparan lebih lanjut terkait nilai-nilai karakter apa saja yang dapat dikembangkan dalam pembelajaran.

Fathul Mu'in (dalam Barnawi dan M. Arifin, 2012:27) menyatakan bahwa pada dasarnya pilar penting karakter manusia terdiri atas 6 hal yakni sebagai berikut: (1) penghormatan (respect); (2) tanggungjawab (responsibility); (3) kesadaran berwarganegara (citizenship-civic duty); (4) keadilan dan kejujuran (fairness); (5) kepedulian dan kemauan berbagi (caring); (6) kepercayaan (trustworthiness).

Selanjutnya Dakir (2004:103-104) memaparkan bahwa tujuan pendidikan karakter yang diinternalisasikan melalui muatan lokal dalam hal ini bahasa Makassar tentu saja tidak dapat terlepas dari tujuan umum yang tertera dalam Garis-Garis Besar Haluan Negara (GBHN). Adapun yang langsung dapat dipaparkan atas dasar tujuan tersebut di antaranya ialah: (1) berbudi pekerti luhur: sopan santun daerah di samping sopan santun nasional, (2) berkepribadian: punya jati diri, (3) mandiri, (4) terampil, (5) beretos kerja, (6) profesional: dapat mengerjakan kerajinan yang khas daerah, misalnya: membatik, membuat wayang, anyam-anyaman, patung dan sebagainya., (7) produktif: dapat berbuat sebagai produsen dan bukan hanya sebagai konsumen, (8) sehat jasmani dan rohani: karena suka bekerja dengan sendirinya akan menjadi sehat jasmani dan rohani (men sana incorpore sano), (9) cinta lingkungan, (10) kesetiakawanan sosial: dalam hal bekerja manusia selalu membutuhkan teman kerja, oleh karenanya akan terjadilah situasi kerja sama atau gotong royong, (11) kreatif dan inovatif untuk hidup, (12) mementingkan pekerjaan yang praktis, dan (13) rasa cinta budaya daerah dan tanah air.

Mengacu pada kedua pendapat di atas, maka seyogyanya pengembangan materi ajar berbasis nilai-nilai karakter dapat mengacu pada aspek-aspek dari tujuan tersebut, sehingga materi ajar yang dihasilkan dapat pula mendorong kemajuan bangsa melalui penerapan GBHN. Di samping nilai-nilai karakter, seorang pengembang materi ajar 
juga harus memperhatikan kearifan lokal masyarakat setempat. Kearifan lokal dapat diartikan sebagai nilai-nilai positif yang tumbuh dan berkembang di tengah-tengah masyarakat yang bersumber dari kebudayaan terdahulu yang berakulturasi dengan kebudayaan modern, sehingga dapat diimplementasikan pada hal-hal yang bersifat modern.

Pandangan orang pada umumnya melihat kearifan lokal sebagai sesuatu yang kolot atau ketinggalan zaman. Namun seiring majunya pendidikan di Indonesia, khususnya di daerah. Kearifan lokal sedikit demi sedikit telah melakukan transformasi menjadi nilai-nilai kehidupan (living values) dan beradaptasi dengan modernitas. Sebagaimana telah dipaparkan di atas bahwa pada dasarnya kearifan lokal merupakan nilai-nilai positif yang telah disampaikan dari generasi ke generasi. Kini saatnya generasi pengembang materi ajar yang mengejawantahkan kearifan lokal tersebut ke dalam materi ajar yang sedang dikembangkan.

Apabila kita berbicara dalam konteks bahasa Makassar, maka kearifan lokal yang diambil tentunya bersumber dari nilai-nilai positif suku Makassar atau lebih luasnya masyarakat Sulawesi Selatan. Tentunya apabila diinventarisasi nilai-nilai tersebut maka akan muncul banyak pilihan, maka dari itu pengembang harus memprioritaskan nilai mana yang harus dikembangkan dengan sasaran seperti apa. Pada bagian selanjutnya nilai-nilai karakter dan kearifan lokal yang dikembangkan akan dibahas.

\section{Materi Ajar yang Dikembangkan}

Setelah melalui serangkaian tahapan pengembangan model pembelajaran yang dilakukan dengan langkah-langkah yang teliti mengacu pada konsep model yang dikembangkan, disertai dengan rujukan-rujukan tentang nilai-nilai karakter dan kearifan lokal. Maka disusunlah materi ajar yang telah dikembangkan berdasarkan hasil penelitian. Sebagaimana hakikat dari konsep model Research and Development (R\&D), maka sebuah pengembangan materi ajar harus berdasarkan penelitian kemudian melakukan pengembangan.

Penelitian terhadap materi ajar yang dikembangkan ini secara singkat diawali dengan penentuan sasaran, selanjutnya di sekolah sasaran tersebut dilakukan analisis kebutuhan siswa yang terdiri dari pengisian kuesioner terkait beberapa aspek yang hendak diteliti dan terkait dengan upaya pengembangan serta pelaksanaan uji pendahuluan (pre-test). Di samping itu, pengembang juga meneliti metode pengajaran yang dilakukan oleh guru pengampu bidang studi serta harapan dari pengambil kebijakan di sekolah dalam hal ini kepala sekolah. Selanjutnya pengembang memformulasikan data yang dikumpulkan dari siswa, guru, dan kepala sekolah sehingga berbentuk tabulasi data yang kemudian dianalisis.

Setelah diketahui kebutuhan dan kemampuan siswa. Maka dilanjutkan dengan meneliti materi ajar yang selama ini digunakan oleh siswa. Dalam meneliti materi ajar, pengembang menggunakan kerangka kerja Littlejohn (dalam Tomlinson, 2007: 190- 
200). Secara umum, kerangka itu terdiri dari dua aspek utama: publikasi dan desain. Yang berhubungan dengan publikasi adalah aspek tampilan fisik bahan ajar, sedangkan desain adalah pemikiran maupun pokok-pokok penting dari bahan ajar.

Setelah melakukan tahapan di atas, maka pengembang sudah bisa merancang model materi ajar yang dikembangkan. Pengembang bisa memulainya dengan struktur sederhana yang mengarah kepada rancangan akhir. Dalam proses pengembangan awal ini disusun beberapa hal seperti silabus dan protipe materi ajar yang meliputi bagianbagian utama, serta penentuan tema yang diangkat setiap bagiannya dalam materi ajar.

Setelah menyelesaikan proses rancangan awal model materi ajar yang dikembangkan, maka dilanjutkan dengan pengujian ahli perancangan pembelajaran dan ahli isi bidang studi. Setelah itu, masukan dari keduanya dapat dijadikan rujukan untuk merancang model final dari model materi ajar yang dikembangkan. Setelah model dianggap final, maka dilakukan uji kelayakan dan keterbacaan pada materi ajar yang dilakukan terhadap siswa kelas eksperimen yang ditentukan. Rancangan final model materi ajar yang dikembangkan strukturnya dapat dilihat sebagai berikut:
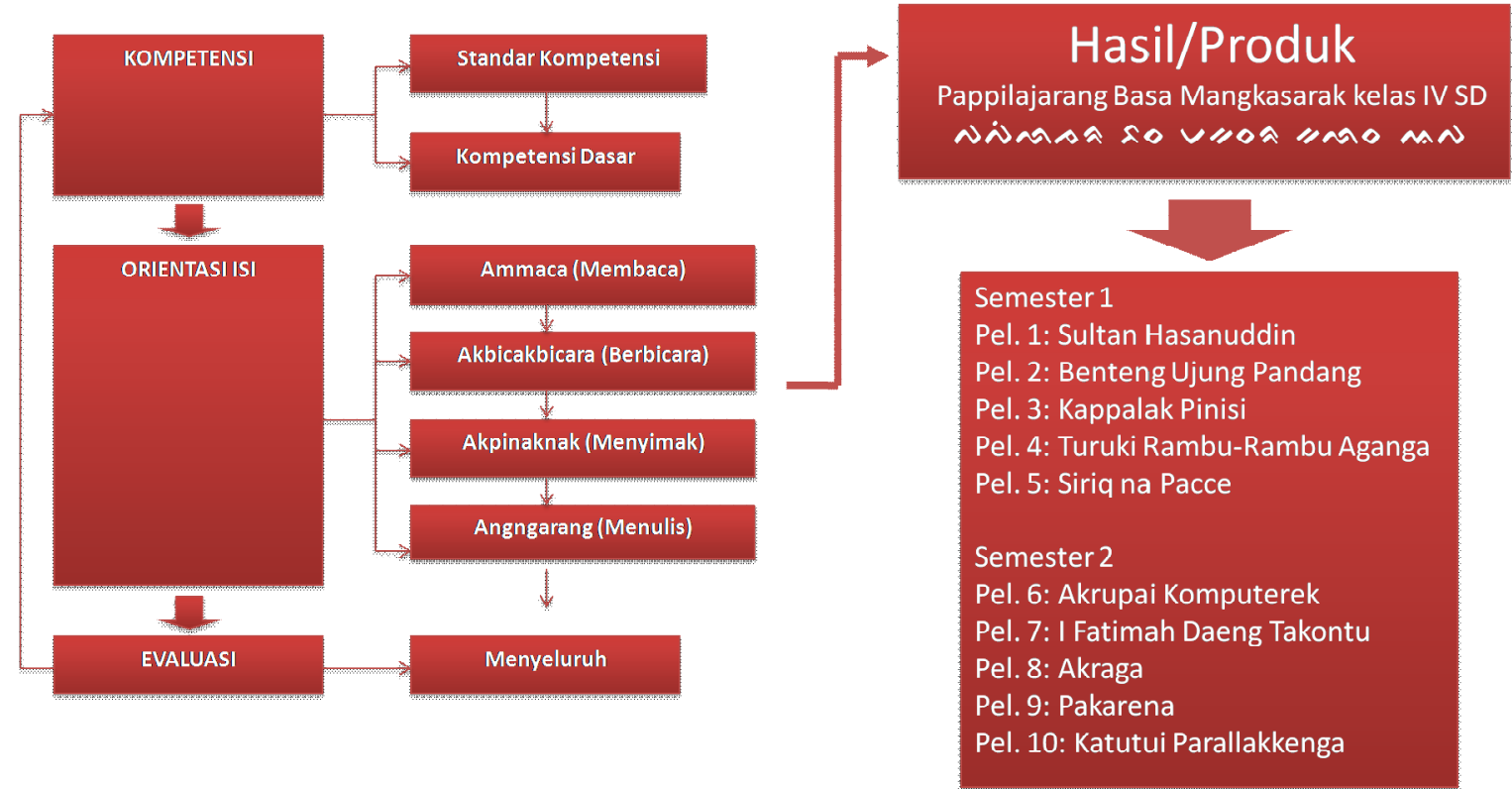

Bagan Rancangan Model "Pappilajarang Basa Mangkasarak" untuk kelas IV SD

Dilihat dari bagan di atas merupakan struktur dari rancangan final model materi ajar yang dikembangkan dan diberi nama "Pappilajarang Basa Mangkasarak" / Pelajaran Bahasa Makassar untuk kelas IV SD. Setelah mengetahui proses singkat membuat sebuah materi ajar, maka selanjutnya akan dibahas secara singkat pula terkait rancangan model "Pappilajarang Basa Mangkasarak" untuk kelas IV SD dan proses internalisasi nilai-nilai karakter dan kearifan lokal pada materi ajar tersebut. Selengkapnya diuraikan sebagai berikut: 


\section{(1) Kompetensi}

Bagian ini terdiri atas standar kompetensi, dan kompetensi dasar yang disingkat dengan SK dan KD. SK berisi tujuan umum yang hendak dicapai oleh siswa dari proses pembelajaran yang dilangsungkan dalam tiap bagian yang disebut 'pelajaran'. Selanjutnya KD berisi tujuan khusus pembelajaran yang terkait dengan indikator pencapaian siswa terhadap proses pembelajaran.

\section{(2) Orientasi Isi}

Bagian ini terdiri dari komponen pembelajaran yang akan melibatkan siswa dan guru. Materi ajar yang digunakan hanya merupakan pedoman serta arahan dalam menentukan pembahasan pada setiap pertemuan. Namun demikian, proses pembelajaran akan sangat tergantung pada keaktifan dan kemampuan siswa maupun guru untuk mengeksplorasi lebih jauh materi ajar yang digunakan ini.

(a) Ammaca (membaca), pada kegiatan ini disediakan bahan bacaan berupa teks maupun dialog. Selanjutnya pada setiap akhir teks/dialog terdapat kosa kata baru dan pertanyaan yang didasarkan pada tema yang dibahas.

(b) Akbicarabicara (berbicara), pada kegiatan ini disediakan berbagai aktivitas yang mengasah keterampilan berbicara siswa, serta meningkatkan rasa percaya diri dalam menggunakan bahasa Makassar.

(c) Akpinaknak (menyimak), pada kegiatan ini dituntut kreativitas guru untuk menyediakan cerita yang terkait dengan tema yang dibahas, kemudian guru membacakan cerita tersebut kepada siswa.

(d) Angngarang (menulis), pada kegiatan ini terdiri dari tiga jenis kegiatan pada bahan ajar ini yakni, penggunaan struktur kata, menerjemahkan aksara lontarak, dan mengarang. Kegiatan ini mengasah keterampilan menulis siswa, serta meningkatkan pemahaman untuk menyampaikan pemikirannya melalui tulisan.

\section{(3) Evaluasi}

Pada setiap akhir pelajaran, dilakukan evaluasi terhadap proses belajar mengajar yang telah dilangsungkan. Hal ini untuk mengukur pemahaman siswa terhadap materi yang telah diajarkan. Dalam evaluasi ini digunakan evaluasi menyeluruh yang melibatkan empat keterampilan berbahasa, yakni membaca, berbicara, menyimak, dan menulis.

Selanjutnya, Pappilajarang Basa Mangkasarak di atas terbagi atas 2 bagian yang diklasifikasi berdasarkan semester yakni Semester 1 dan Semester 2. Tiap semesternya terdiri atas 5 pelajaran, sehingga total ada 10 pelajaran dalam 1 materi ajar. Topik yang dibahas antara lain:

1) Sultan Hasanuddin (Kepahlawanan)

2) Benteng Ujung Pandang/Fort Rotterdam (Tempat Bersejarah) 
3) Kappalak Pinisi/Perahu Pinisi (Transportasi)

4) Turuki rambu-rambu aganga/ikuti rambu-rambu lalu lintas (Kedisiplinan)

5) Siri' na Pacce/malu dan empati (Sikap/Budi Pekerti)

6) Akruppai Komputerek/Mengenal Komputer (Teknologi)

7) I Fatimah Daeng Takontu (Tokoh Perempuan)

8) Akraga/Bermain Sepak Raga (Olahraga)

9) Pakarena (Kesenian)

10) Katutui Paralakkenga/Pelihara Lingkungan (Lingkungan Hidup)

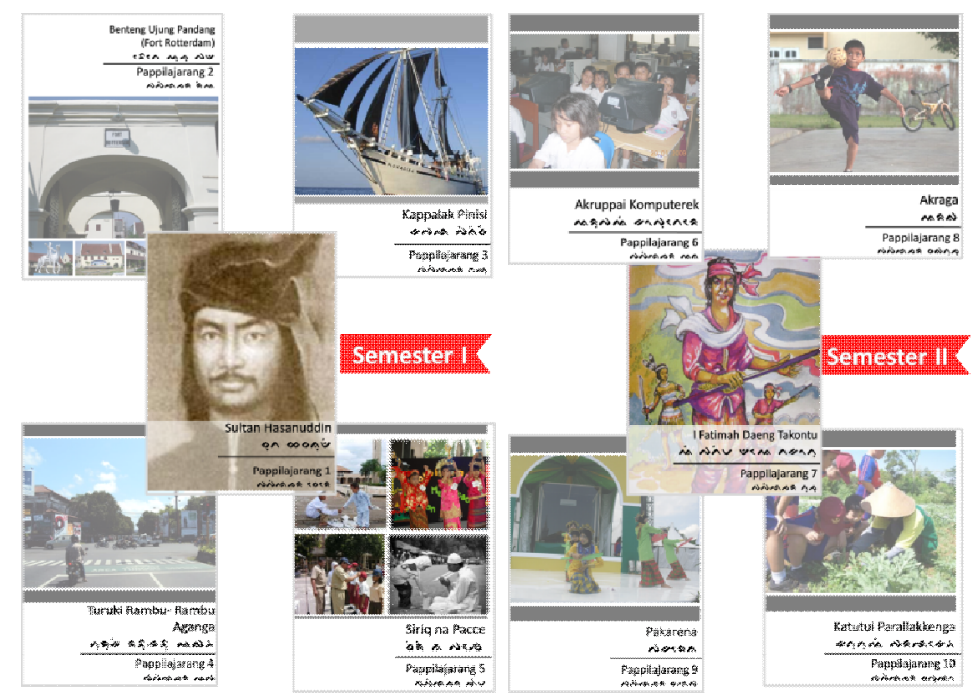

Pappilajarang Basa Mangkasarak untuk Kelas IV SD (Sitti Rabiah, 2012b)

Pemilihan topik di atas ditentukan berdasarkan nilai-nilai yang hendak disampaikan kepada siswa/peserta didik. Seperti Sultan Hasanuddin dalam tema Kepahlawanan. Pada topik ini pengembang ingin menyampaikan bahwa kepahlawanan dari Sultan Hasanuddin yang notabene adalah Raja yang pernah memimpin kerajaan di Makassar patut menjadi suri tauladan bagi siswa.

Begitu juga dengan Benteng Ujung Pandang/Fort Rotterdam (Tempat Bersejarah) dan Kappalak Pinisi/Perahu Pinisi (Transportasi) dulunya tempat dan alat transportasi ini dikenal luas oleh masyarakat di Sulawesi Selatan, namun demikian seiring perkembangan zaman keberadaannya mulai dilupakan. Namun melalui pembelajaran kedua hal ini dapat diperkenalkan kembali kepada generasi muda.

Selanjutnya topik Turuki rambu-rambu aganga/ikuti rambu-rambu lalu lintas (Kedisiplinan) dan Akruppai Komputerek/mengenal komputer (Teknologi) merupakan keseharian yang sering ditemui oleh siswa. Sehingga ada pesan-pesan yang bisa disampaikan melalui materi ajar terkait dengan imbauan terhadap tertib berlalu lintas serta mengenalkan teknologi komputer walaupun melalui pelajaran bahasa Makassar.

Lain halnya dengan siri' na pacce/malu dan empati (Sikap/Budi Pekerti), secara eksplisit masyarakat mengerti dan tahu terhadap kearifan lokal yang satu ini. Namun seringkali susah mendeskripsikannya kepada generasi muda, sehingga kearifan lokal ini sering disalahartikan sebagai sikap yang terlalu mengedepankan ego yang dianggap harga diri di masyarakat. Padahal kearifan lokal ini ingin menyampaikan pesan bahwa 
setiap orang harus malu ketika tidak berprestasi dan berempati kepada mereka yang susah. Pesan inilah yang disampaikan dalam materi ajar ini.

Sama halnya dengan tema Kepahlawanan, bagian Semester 2 diawali dengan bagian yang dapat menggugah siswa yakni mengangkat topik Tokoh Perempuan 'I Fatimah Daeng Takontu'. Ia merupakan anak langsung dari Sultan Hasanuddin, namun hal ini sangat jarang dimengerti oleh generasi muda. Ia dapat dijadikan teladan atas dasar keberanidan dan baktinya kepada orang tua, sehingga ia turun ke medan peperangan di kala itu melawan penjajah bersama pasukan yang dipimpin oleh ayahnya. Sehingga ia merupakan sosok perempuan yang tegar dan berwibawa. Topik ini tentunya dapat meningkatkan motivasi bagi siswa perempuan yang mungkin merasa kecil di tengah-tengah pergaulan.

Di samping itu, materi ajar ini juga memperkenalkan kembali kebudayaan tradisional yang terdapat pada topik Akraga/Bermain Sepak Raga (Olahraga) dan Pakarena (Kesenian). Kedua hal ini merupakan olahraga dan kesenian yang populer dahulu, namun kembali lagi keduanya menghilang seiring perkembangan zaman. Melalui topik ini diharapkan siswa dapat lebih mengenal kebudayaannya ini.

Terakhir topik yang tidak kalah pentingnya yakni Katutui Parallakkenga/Pelihara Lingkungan di dalam topik Lingkungan Hidup. Topik ini sangat terkait dengan kondisi kekinian di Indonesia maupun di dunia internasional. Kampanye global tentang perubahan iklim dan pemanasan global tentunya menjadi hal yang perlu diketahui oleh generasi muda. Bahkan banyak pendapat yang menyatakan bahwa kepedulian terhadap lingkungan harus dimulai dari usia dini, salah satu yang bisa diupayakan yakni memperkenalkan topik ini kepada siswa sekolah dasar.

Berdasarkan paparan singkat dari tiap topik di atas, maka dapat dipahami bahwa pada dasarnya nilai-nilai karakter dapat diinternalisasikan dalam proses pembelajaran walaupun pelajaran tersebut yakni bahasa Makassar. Di samping itu, kebudayaan dan kearifan lokal yang selama ini dilupakan dapat juga diangkat kembali melalui pembelajaran. Bahkan kampanye global dapat juga dipahamkan kepada siswa agar turut berkontribusi secara internasional. Sebagaimana sebuah jargon yang seringkali dikampayekan yakni "Think Globally, Act Locally" yang merupakan bentuk ajakan untuk berfikir secara global, namun menindaklanjutinya di tingkat lokal.

Materi ajar yang telah dikembangkan ini tentunya berdampak pada semangat belajar siswa. Sehingga pelajaran bahasa Makassar yang dulunya membosankan dan hanya sebagai pelengkap mata pelajaran, kini dapat semakin menarik dan informatif. Namun hal yang perlu diingat bahwa sebuah materi ajar tentunya memerlukan pembaruan setiap 5 tahun, maka dari itu materi ajar ini dapat senantiasa relevan dengan perkembangan zaman. 


\section{PENUTUP}

\section{Kesimpulan}

Berdasarkan paparan di atas maka tentunya sudah dapat dipahami bahwa reaktualisasi pembelajaran bahasa daerah di tingkat sekolah dasar dengan melakukan pengembangan terhadap materi ajar berbasis nilai-nilai karakter dan kearifan lokal sangat dimungkinkan dalam rangka membentengi generasi muda dari dampak negatif yang dapat ditimbulkan oleh globalisasi dan kemajuan teknologi.

Lebih lanjut materi ajar tersebut dapat disesuaikan dengan kebutuhan dan pencapaian yang hendak dituju baik oleh pemerintah pusat, maupun daerah dalam membentuk karakter siswa, khususnya siswa sekolah dasar. Tentunya nilai-nilai karakter yang diberikan adalah hal-hal yang positif dan dapat membekali siswa menjadi pribadi yang berintegritas.

Melalui makalah ini semoga dapat menginspirasi pengembang bahasa daerah di seluruh Indonesia dalam rangka menjadikan bahasa daerah menjadi gerbang bagi peningkatan karakter siswa di berbagai jenjang. Karena dampak yang diberikan akan semakin besar bilamana dilakukan bersama-sama dan terkoordinasi.

\section{Rekomendasi}

Pengembangan materi ajar bahasa daerah di seluruh Indonesia hendaknya sudah berbasis pada nilai-nilai karakter dan kearifan lokal agar materi ajar tersebut tidak kolot dan ketinggalan zaman. Kecenderungan siswa menyepelekan bahasa daerah bukan karena kesalahan siswa sendiri, namun dapat juga dilihat dari upaya Dinas Pendidikan serta instansi pemerintah terkait dalam menyuplai materi ajar yang mampu membangkitkan semangat siswa untuk belajar dan belajar sebagaimana konsep belajar sepanjang hayat.

\section{REFERENCES}

Alwi, Hasan dan Dendy Sugono. 2003. Politik Bahasa Nasional. Jakarta: Pusat Bahasa. Asmani, Jamal Ma'mur. 2011. Buku Panduan Internalisasi Pendidikan Karakter di Sekolah. Yogyakarta: Diva Press.

Barnawi dan M. Arifin. 2012. Strategi dan Kebijakan Pembelajaran Pendidikan Karakter. Yogyakarta: Ar-Ruzz Media.

Borg, Walter R. dan Meredith Damien Gall. 2003. Educational Research: An Introduction Seventh Edition. Boston: Allyn and Bacon.

Brown, James Dean. 1995. The Elements of Language Curriculum: A Systematic Approach to Program Development. Boston: Heinle\&Heinle Publisher.

Dakir, H. 2004. Perencanaan dan Pengembangan Kurikulum. Yogyakarta: PT. Rineka Cipta. 
Halim H., Abd. 2007. Pengembangan Model Bahan Ajar. Jakarta: Pustaka Press.

Joyce, Bruce, Marsha Weil, dan Emily Calhoun. 2009. Models of Teaching: ModelModel Pengajaran edisi delapan diterjemahkan Achmad Fawaid dan Ateilla Mirza. Yogyakarta: Pustaka Pelajar.

Kementerian Pendidikan dan Kebudayaan. 2011. Pembelajaran Kontekstual dalam Membangun Karakter Siswa. Jakarta: Kemdikbud.

Mulyana, E. 2003. Kurikulum Berbasis Kompetensi, Konsep, Karakteristik, dan Implementasi. Yogyakarta: Remaja Rosdakarya.

Pribadi, Benny A. 2010. Model Desain Sistem Pembelajaran. Jakarta: Dian Rakyat.

Rabiah, Sitti. 2012a. "Model Bahan Ajar Bahasa Makassar sebagai Muatan Lokal: Penelitian dan Pengembangan di Sekolah Dasar kota Makassar". (Disertasi), Universitas Negeri Jakarta.

Rabiah, Sitti. 2012b. Pappilajarang Basa Mangkasarak untuk Kelas IV Sekolah Dasar. Yogyakarta: Gemini Publishing.

Rabiah, Sitti. 2012c. Revitalisasi Bahasa Daerah Makassar melalui Pengembangan Bahan Ajar Bahasa Makassar sebagai Muatan Lokal. Dipresentasikan dalam Kongres Internasional II Bahasa-Bahasa Daerah Sulawesi Selatan Tahun 2012. Makassar: Balai Bahasa Provinsi Sulawesi Selatan dan Provinsi Sulawesi Barat. doi: 10.31227/osf.io/bu64e .

Singer, Dorothy G. dan Tracey A. Revenson. 1996. A Piaget Primer: How a Child Thinks Revised Edition. New York: Plume.

Tomlinson, Brian. 2007. Developing Materials For Language Teaching. London: Continuum.

Trianto. 2011. Mendesain Model Pembelajaran Inovatif-Progresif: Konsep, Landasan, dan Implemetasinya pada Kurikulum Tingkat Satuan Pendidikan (KTSP). Jakarta: Kencana, 2011.

Wahid, Sugira. 2007. Manusia Makassar. Makassar: Pustaka Refleksi. 